\title{
Seasonal incidence and bionomics of rose aphid, Macrosiphum rosae (Linnaeus, 1758), (Hemiptera: Aphididae) in Kashmir, India
}

\author{
Insha YOUSUF ${ }^{1,2}$ and Abdul A. BUHROO ${ }^{1}$
}

Received May 30, 2019; accepted March 3, 2020.

Delo je prispelo 30. maja 2019, sprejeto 03. marca 2020

\begin{abstract}
Seasonal incidence and bionomics of rose aphid, Macrosiphum rosae (Linnaeus, 1758), (Hemiptera: Aphididae) in Kashmir, India

Abstract: Rose is the principal flower of the world floriculture industry that is being exclusively used as cut flower, potted plant and garden plant. It plays significant part in numerous industries viz. food, perfumery and cosmetic industries. About $96 \%$ of women's perfumes contain true Bulgarian rose oil. Roses are well acclimatized in Jammu \& Kashmir because of its suitable agro climatic conditions which can permit its large scale production and rose products produced in the state are at par with the international standards. But the aesthetic and commercial value of roses is greatly lowered by numerous insect pests resulting in low yield. However, its major pest include aphid species most notoriously Macrosiphum rosae that pose many challenges and threats to rose plant cultivation. Aphid colonies on roses result in reduction of medical value of the plant and cause economic losses to growers particularly during spring and summer season. In order to reduce the economic losses inflicted by rose aphid, it is necessary to study different biological parameters of this pest species so that an effective management plan can be formulated.
\end{abstract}

Key words: floriculture; rose; Macrosiphum rosae; economic losses; biological parameters
Sezonsko pojavljanje in bionomika vrtnične uši (Macrosiphum rosae (Linnaeus, 1758), Hemiptera: Aphididae) v Kašmirju, Indija

Izvleček: Vrtnica je glavna cvetlica v svetovni florikulturni industriji, ki se uporablja za rezano cvetje, kot lončnica in zasaditev vrtov. Ima pomembno vlogo v različnih industrijskih panogah kot so živilstvo, parfumerska in kozmetična industrija. Okrog 96 \% ženskih parfumov vsebuje olje prave bolgarske vrtnice. Vrtnice so dobro prilagojene razmeram v Jammu in Kašmirju zaradi primernih agroklimatskih razmer, ki omogočajo velikopovršinsko gojenje vrtnic in proizvodi iz njih so v državi pripravljeni po mednarodnih standardih. Estetsko in komercialno vrednost vrtnic v veliki meri zmanjšujejo številne škodljive žuželke, kar zmanjšuje pridelek. Največji škodljivci so listen uši in med njimi vrtnična uš (Macrosiphum rosae (Linnaeus, 1758)), ki predstavlja resen izziv gojenju vrtnic. Kolonije listnih uši na vrtnicah zmanjšujejo medicinsko vrednost vrtnic in povzročajo ekonomsko izgubo pridelovalcem, še posebej spomladi in poleti. $\mathrm{Z}$ namenom zmanjšanja ekonomskih izgub, ki jih povzročajo listne uši na vrtnicah, je potrebno preučiti različne biološke parametre tega škodljivca za pripravo plana učinkovitega upravljanja.

Ključne besede: florikultura; vrtnica; Macrosiphum rosae; ekonomske izgube; biološki parametri

1 University of Kashmir, Department of Zoology, Division of Entomology, Jammu and Kashmir, India

2 Corresponding author, e-mail: inshayousuf444@gmail.com 


\section{INTRODUCTION}

Rose is an attractive pricky ornamental shrub belonging to genus Rosa of family Rosaceae. It possesses a climbing or trailing habit and is commonly called as "Queen of Flowers". Roses are exclusively used in beauty and decorations, without these gardens are not considered complete. Apart from adoration, attar extracted from roses is used in making various fragrant mixtures. Roses produce rose oil, rose water, all of which are valuable and important base material for a number of industries such as perfume, pharmaceutical and cosmetic (Ayci et al., 2005). But the main use of roses is in cut flower industry and landscaping.

Roses are also well- known for their medicinal value and are used in manufacture of large number of medicines. The rose hips which are valued for food are also the richest natural source of vitamin $\mathrm{C}$ (having thrice more Vitamin $C$ content than citrus fruits) and are pressed commercially to give rose hip syrup that has been long used to prevent scurvy (Anonymous, 1982). Rose hip herbal tea helps to strengthen the immune system and can further prevent colds and flu (Ziegler et al., 1986). Medicinally, it is also an important nervine used to treat depression and anxiety. Roses possess a unique ability to firm boggy or damaged tissue, reduce inflammation and lessen bacterial proliferation while encouraging the growth of healthy tissue which makes it ideal in the treatment of many microbial infections (Jacoby \& Wokes, 1944). Mahmood et al., (1996) and Basim \& Basim (2003) reported anti HIV properties of rose oil and its ability to stop and kill some strains of Xanthomonas.

However, roses are inhabited by numerous pests which include moths from the family Tortricidae, Hymenoptera from the family Tenthredinidae, Argidae and
Cynipidae as well as numerous aphid species. Out of which, the aphid species, Macrosiphum rosae (Linnaeus, 1785 ) is a key pest of roses, with worldwide distribution (Blackman and Eastop, 2000). The significant damage by rose aphid is to the inflorescences, especially at bud burst (Fig. 1). This species cause direct damage by sap sucking from young leaves and developing flower buds which in turn results in discoloration of leaves, stunted growth and gall formation, while as indirect loss is incurred by honeydew secretion on flowers and surface of leaves on which molds grow resulting in reduction in photosynthesis and finally the yield (Jalalizand, 2012). All these factors together cause significant damage to rose plants by decreasing their beauty and the value of cut flowers. Rose aphid is also involved in transmitting viral diseases such as pea mosaic, cauliflower mosaic and cabbage black ring spot (Manddahar, 1987).

Now- a- days, floriculturists round the world do not recommend use of insecticides on flowers and as such aphids are controlled by predators and parasitoids (Bari and Sardar, 1998). As a result, increasing number of studies involving biological control of aphids by natural enemies has become an important feature of pesticide free management strategies (Zehnder et al., 2007). Mehrparvar et al., 2016 reported that natural enemies of M. rosae include four species of Coccinellidae [Hippodamia variegata (Goeze, 1777), Coccinella septempunctata (Linnaeus, 1758), Adalia bipunctata (Linnaeus, 1758) and Exochomus nigromaculatus (Goeze, 1777)], three species of Syrphidae [Syrphus vitripennis Meigen 1822, Ischiodon aegyptius (Wiedemann, 1830) and Scaeva albomaculata (Macquart, 1842)], two species of Chamaemyiidae [(Leucopis glyphinivora Tanasijitshuk, 1958 and Leucopis spp. Meigen, 1830], one species of Chrysopidae [Chrysoperla carnea (Stephens, 1836)], a few species of Anthocoridae [Orius niger (Wolff, 1811) Orius minutus

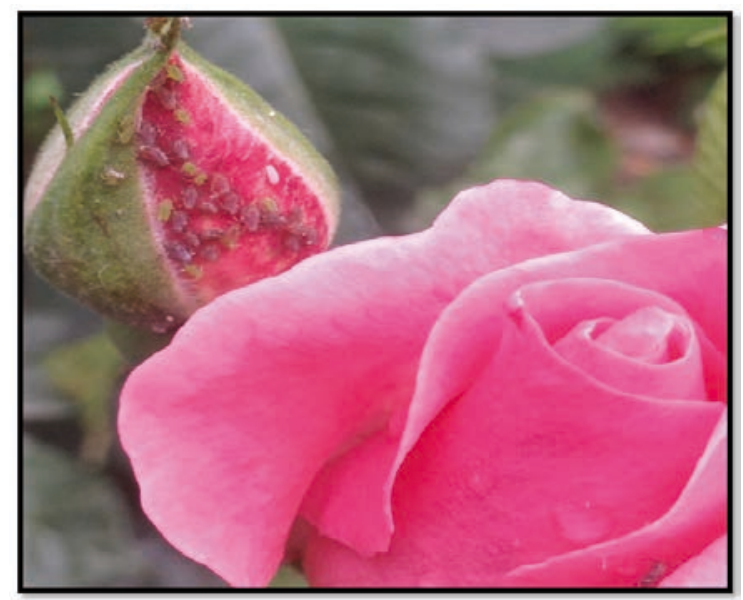

Figure 1: Infestation of young flower bud by $M$. rosae 
(Linnaeus, 1758) and Anthocoris limbatus Fieber, 1836] and Miridae [Deraeocoris punctulatus (Fallen, 1807) and Deraeocoris spp.(Kirschbaum, 1856)], all of these act as predators of rose aphid and four species of parasitoids i.e., Braconidae parasitic wasps [Aphidius rosae Haliday 1833, Aphidius ervi Haliday, 1834, Praon volucre (Haliday, 1833) and Ephedrus plagiator (Nees, 1811)] in Iran. In addition to this, numerous researchers viz. Chakrabrati and Gosh, 1970; Maezler, 1977; Mohammed and Mallah, 1987; Tomiuk et al., 1990; Jaskiewicz, 1995; Dixon and Agarwala, 1999, Gadakh, 2014 etc have worked on various aspect of different rose aphid species under different climatic conditions and have obtained varied results but in Kashmir little information is available on this particular insect pest. A precise knowledge about seasonal incidence and biology of pest is essential for any effective control plan to succeed. Keeping in view the economic importance of roses, the degree of damage inflicted by $M$. rosae and in order to develop a sound pest management strategy against it, the present investigation was carried out to study its incidence, population build up and biology along with the relative susceptibility of different rose cultivars to $M$. rosae.

\section{MATERIAL AND METHODS}

\subsection{PERCENTAGE INCIDENCE OF $M$. rosae}

Random surveys were carried out fortnightly at special rose growing ornamental gardens in Srinagar district of Kashmir for collection of rose aphids from March to December 2015. These include Shalimar, Nishat, Kashmir University Botanical Garden (KUBG) and Naseem bagh campus. At all experimental sites, five plants were randomly selected and from each plant three twigs were examined for calculation of aphid infestation. The aphids were brushed off from apical tender portions i.e. shoots, buds, flowers and occasionally from underside of leaves of rose plants using camel hair brush on to a white paper and counted to determine aphid severity at different locations. For calculation of percentage of brown, green, alate and apterous forms, separate counts were done from onset of aphids on rose plants till their disappearance.

The apical portions of rose plants were considered infested even if only one aphid was observed on it whereas un- infested rose plants were devoid of any rose aphid. Percentage incidence was calculated by the formula

Incidence $=\mathrm{n} / \mathrm{N} \times 100$

Where, $\mathrm{n}=$ number of infested shoots

$\mathrm{N}=$ total number of shoots examined.

\subsection{IDENTIFICATION OF ROSE APHID}

Identification of the pest was done by studying their morphological characters under microscope and comparing them with literature available on their morphology. The diagnosis of the species was confirmed according to key provided by David (1975).

\subsection{STOCK CULTURE OF ROSE APHID}

In order to study biology, a stock culture of rose aphids was maintained on fresh, tender apical portions of rose plants in the Entomology Research Laboratory of Department of Zoology, University of Kashmir under natural conditions of temperature and humidity. Rose aphids were brushed off from infested rose plant portions using camel hair brush into collection tubes. In the case of heavy infestation, apical $10 \mathrm{~cm}$ tender shoots were trimmed carefully, put in sealed polythene bag, and carried to the laboratory (Reshi et al., 2008). Fresh food in the form of fresh tender apical rose plant portions were provided to them on daily basis and these were kept in large beakers which in turn were placed in large glass rearing jars having their open end covered with muslin cloth for ventilation.

\subsection{STUDY OF DIFFERENT BIOLOGICAL PA- RAMETERS OF ROSE APHIDS}

Adult apterous viviparous parthenogenetically producing female rose aphids collected from field were placed singly on potted rose plant in the laboratory and left overnight for laying young ones. After $12 \mathrm{hrs,} \mathrm{all}$ mothers except a newly laid nymph were removed from each plant and kept in $70 \%$ alcohol. The nymph was reared and examined daily from its birth till death for recording different biological parameters. Observations were recorded on duration and number of nymphal instars, pre- reproductive, reproductive, post reproductive period and adult longevity (Ghetiya, 1992). The data was collected for apterous and alate forms separately in two seasons i.e. late spring (May- June) and autumn (October- November). Each parameter was replicated thrice.

\subsection{RESPONSE OF DIFFERENT Rosa SPP. TO $M$. rosae}

The response of different cultivars of Rosa spp to $M$. rosae was studied under natural field conditions at Kashmir University Botanical Garden viz. Grand Gala, 
Golden Gate, Konfettii, Naranga and Nobless. Aphid intensity was recorded separately for each cultivar of Rosa spp. at fortnightly interval by examining apical $10 \mathrm{~cm}$ portion of rose plant. The observations were recorded from the appearance of aphid in the field and experiment for each species was repeated five times. Mean aphid intensity was calculated by transforming the observations to corresponding square root values. Further, the relative susceptibility of different cultivars was determined on the basis of relative mean population load during the study period and categorized following Malik \& Deen (1998):

1. Highly resistant (HR): value between 0.0 to mean - Critical difference (CD)at $5 \%$ level

2. Resistant (R): value between HR to mean - CD at $5 \%$ level
3. Moderately resistant (MR): value between $\mathrm{R}$ to mean

4. Low resistant (LR): value between MR to mean + $\mathrm{CD}$ at $5 \%$ level

5. Susceptible (S): value between LR to mean $+C D$ at $5 \%$ level

6. Highly susceptible (HS): value above $S$

\section{RESULTS}

\subsection{SEASONAL INCIDENCE OF M. rosae INFEST- ING ROSES}

The data from different localities of Srinagar, Kashmir on aphid no/ twig i.e. aphid infestation and percentage incidence (Table $1 \& 2$ ) revealed that insect pest

Table 1: Infestation of rose aphid, M. rosae at four different sites of Srinagar district from March to December 2015

\begin{tabular}{lllllll}
\hline S. No. & Month & KUBG & Nishat & Shalimar & Naseem bagh & Mean aphid infestation* \\
\hline 1 & March & 0.00 & 0.17 & 0.23 & 0.00 & 0.40 \\
2 & April & 9.00 & 7.13 & 12.60 & 8.47 & 9.30 \\
3 & May & 29.03 & 32.06 & 34.86 & 25.15 & 30.27 \\
4 & June & 1.70 & 9.93 & 12.26 & 0.38 & 6.07 \\
5 & July & 0.13 & 1.5 & 2.03 & 0.00 & 0.91 \\
6 & August & 6.26 & 11.93 & 15.33 & 4.66 & 9.50 \\
7 & September & 21.40 & 24.02 & 27.00 & 17.80 & 22.55 \\
8 & October & 4.87 & 7.20 & 10.93 & 9.53 & 8.13 \\
9 & November & 1.07 & 2.87 & 3.00 & 2.01 & 2.23 \\
10 & December & 0.00 & 0.27 & 0.33 & 0.00 & 0.60
\end{tabular}

*Mean based on aphid population counted on 3 twigs/ plant/ site.

Table 2: Incidence of M. rosae at four experimental sites of district Srinagar, Kashmir

\begin{tabular}{|c|c|c|c|c|c|c|}
\hline \multirow[b]{2}{*}{ S. No. } & \multirow[b]{2}{*}{ Month } & \multicolumn{4}{|c|}{ Percentage incidence } & \multirow[b]{2}{*}{ Mean* } \\
\hline & & KUBG & Nishat & Shalimar & Naseem bagh & \\
\hline 1 & March & 0.00 & 13.66 & 19.42 & 0.00 & 8.27 \\
\hline 2 & April & 30.00 & 37.66 & 42.00 & 27.33 & 34.25 \\
\hline 3 & May & 72.02 & 87.00 & 102.00 & 63.13 & 81.04 \\
\hline 4 & June & 20.12 & 54.22 & 60.00 & 13.66 & 37.00 \\
\hline 5 & July & 20.00 & 14.00 & 26.66 & 0.00 & 15.16 \\
\hline 6 & August & 24.13 & 33.33 & 50.00 & 20.66 & 32.03 \\
\hline 7 & September & 66.00 & 70.33 & 82.66 & 40.00 & 64.75 \\
\hline 8 & October & 46.33 & 33.66 & 40.00 & 20.00 & 35.00 \\
\hline 9 & November & 12.00 & 19.00 & 25.33 & 8.00 & 16.08 \\
\hline 10 & December & 0.00 & 10.66 & 14.00 & 0.00 & 6.16 \\
\hline
\end{tabular}

${ }^{*}$ Mean based on aphid population counted on 3 twigs/ plant/ site. 


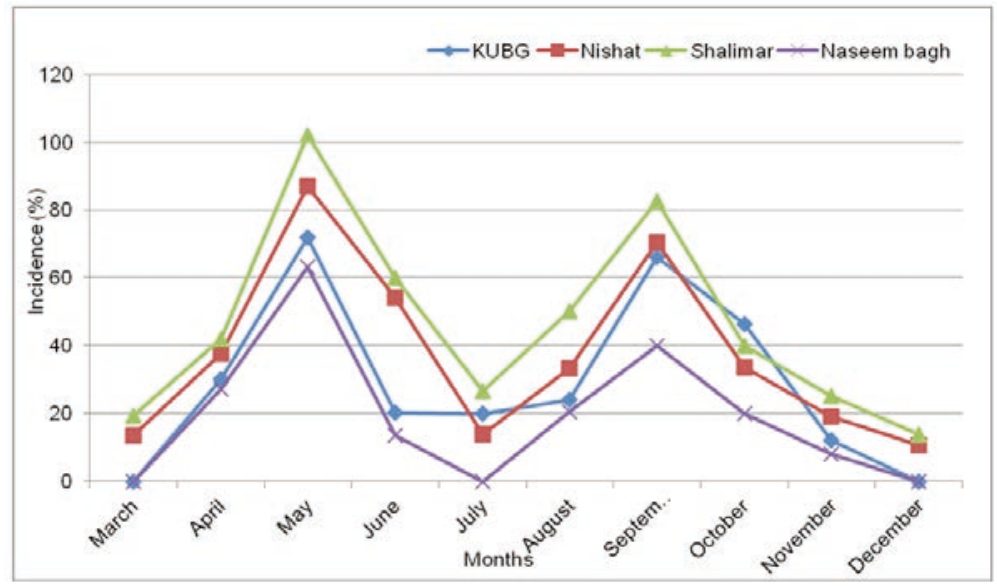

Figure 2: Monthly incidence of M. rosae at four sites of district Srinagar, Kashmir

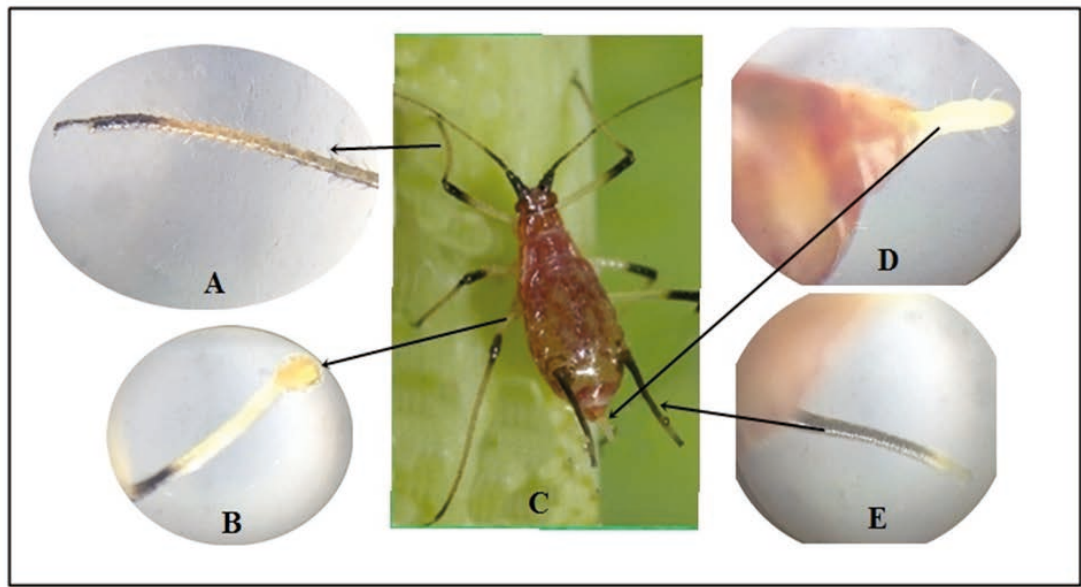

Figure 3: Identification of M. rosae. A. Tibia, B. Femur, C. Adult, D. Cauda and E. Siphunculi

occurred during March at Nishat and Shalimar having mean aphid no/ twig and percentage incidence of 0.17 and 0.23 and 13.66 and 19.42 at two sites respectively. The pest population reached its first peak at all sites during May with mean aphid no/ twig recorded as 29.03, $32.06,34.86$ and 25.15 while percentage incidence was 72.02, 87.00, 102.00 and 63.13 for KUBG, Nishat, Shalimar and Naseem bagh respectively. Afterwards, a rapid reduction in aphid no / twig and percentage incidence of pest population was observed at all sites till July. However, the aphid population starts building up from August and reached to its $2^{\text {nd }}$ peak in September with mean aphid no. / twig 21.40, 24.02, 27.00 and 17.80 with percentage incidence of $66.00,70.33,82.66$ and 40.00 at KUBG, Nishat, Shalimar and Naseem bagh respectively (Fig. 2). The pest population as per mean aphid no/ twig and percentage incidence showed reduction in October and November. During December the pest population was observed at Nishat and Shalimar but it completely disappeared at KUBG and Naseem bagh.

\subsection{PEST IDENTIFICATION}

The study on various morphological features of adult apterous viviparous specimens collected from district Srinagar revealed that this insect pest is medium sized, broadly spindle shaped with dark head, siphunculi (a pair of horn shaped tubes on abdomen) dark throughout that bent outside and reticular at distal end (Fig. 3). The average antennal length was $3.6 \mathrm{~mm}$, with a cluster of rhinaria arranged all over the surface at the base of $3^{\text {rd }}$ antennal segment, caudal end possessing 10- 14 hairs and leg femora and tibiae wee pale at the base and dark black in distal parts. These morphological characters were compared with taxonomic review of genus Macrosiphum occurring in India, provided by David (1975) 
and Blackmann \& Eastop (2000) and it was concluded that the insect pest is $M$. rosae.

\subsection{PERCENTAGE OF BROWN AND GREEN MORPHS OF $M$. rosae}

The data obtained from the fields on percentage of brown and green morphs of $M$. rosae are depicted in Table 3. From the data on overall population of both brown and green aphids, it is clear that brown morphs varied from $54.79 \%$ to $60.00 \%$ which is slightly higher than green morph ranging from $40.00 \%$ to $45.20 \%$. Further, both brown and green morphs were observed on the plants at the same time throughout the infestation season i.e. colour morphs were normally distributed but slightly biased towards the brown morphs (Fig. 4).

\subsection{PERCENTAGE OF ALATE AND APTEROUS FORMS OF $M$. rosae}

The data on percentage of alate and apterous forms is represented in Table 4 which indicates that a significant percentage of alate form ranging from $16.00 \%$ to
$20.51 \%$ while as apterous form range from $79.48 \%$ to $84.00 \%$ were observed in the beginning of season. Afterwards, the percentage of alate forms declined as low as $3.19 \%$ in the $1^{\text {st }}$ week of August. Later, their percentage increased considerably and outnumbered the apterous forms towards the end of the season ranging from $39.64 \%$ to $81.82 \%$ of adult population in the first week of November.

\subsection{BIOLOGY OF ROSE APHID, M. rosae}

The present studies on the biological aspects conducted on stock culture of rose aphids maintained on tender apical portions of rose plant under laboratory conditions revealed that these aphids undergo both parthenogenetic and viviparous modes of reproduction producing both wingless and winged forms. In vivo observations on the biological aspects of the rose aphid were indicative of the fact that the newly born nymphs passed through four nymphal instars before molting into adult. The data on duration of nymphal instars and total developmental period for apterous as well as for alate form of the rose aphids in two seasons i.e. late spring and autumn are given in Table 5 .

Table 3: Percentage of brown and green morphs of $M$. rosae at four selected sites of Srinagar, Kashmir

\begin{tabular}{lllllll}
\hline S. No. & Sites & $\begin{array}{l}\text { Total aphid popu- } \\
\text { lation* }\end{array}$ & $\begin{array}{l}\text { Brown aphid popu-Green aphid popu- Percentage of } \\
\text { lation }\end{array}$ & lation & $\begin{array}{l}\text { Percentage of green } \\
\text { brown morphs }\end{array}$ \\
\hline 1 & KUBG & 826 & 470 & 356 & 56.90 & 43.09 \\
\hline 2 & Nishat & 1268 & 726 & 542 & 57.26 & 42.74 \\
\hline 3 & Shalimar & 1635 & 981 & 654 & 60.00 & 40.00 \\
\hline 4 & Naseem bagh & 584 & 320 & 264 & 54.79 & 45.20 \\
\hline
\end{tabular}

${ }^{*}$ Data based on aphid population on 3 twigs/ host plant/ site.

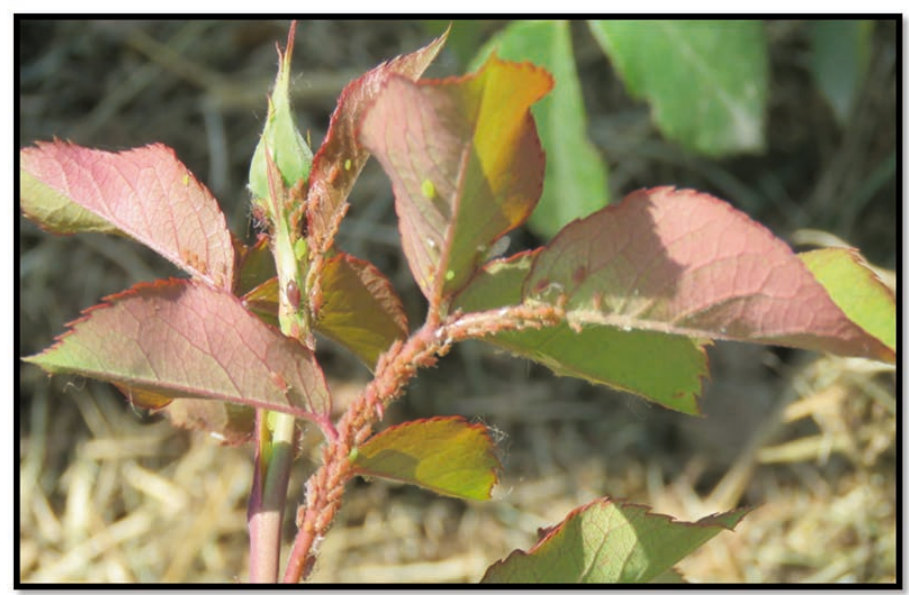

Figure 4: Severe infestation of apical portions of rose plant by brown and green morphs of rose aphid, M. rosae 
Table 4: Percentage of alate and apterous forms of M. rosae at KUBG, Srinagar during 2015

\begin{tabular}{|c|c|c|c|c|c|c|}
\hline S. No. & Month & $\begin{array}{l}\text { Total aphid popula- } \\
\text { tion }\end{array}$ & $\begin{array}{l}\text { Apterous aphid } \\
\text { population }\end{array}$ & $\begin{array}{l}\text { Alate aphid popula- } \\
\text { tion }\end{array}$ & $\begin{array}{l}\text { Percentage of apter- } \\
\text { ous aphid form }\end{array}$ & $\begin{array}{l}\text { Percentage of } \\
\text { alate aphid form }\end{array}$ \\
\hline 1 & March & 50 & 42 & 8 & & 16.00 \\
\hline 2 & April & 320 & 230 & 90 & 71.87 & 28.12 \\
\hline 3 & May & 848 & 674 & 174 & 79.48 & 20.51 \\
\hline 4 & June & 178 & 167 & 11 & 93.82 & 6.18 \\
\hline 5 & July & 94 & 91 & 3 & 96.80 & 3.19 \\
\hline 6 & August & 128 & 121 & 7 & 94.53 & 5.46 \\
\hline 7 & September & 386 & 353 & 8 & 91.45 & 8.55 \\
\hline 8 & October & 565 & 341 & 224 & 60.35 & 39.64 \\
\hline 9 & November & 98 & 30 & 68 & 30.61 & 69.39 \\
\hline 10 & December & 22 & 4 & 18 & 18.18 & 81.82 \\
\hline
\end{tabular}

${ }^{*}$ Data based on aphid population on 3 twigs/ host plant/ site.

Table 5: Duration of various developmental stages of $M$. rosae in two different seasons of Kashmir valley

\begin{tabular}{|c|c|c|c|c|c|c|c|c|}
\hline \multirow[b]{2}{*}{ Season } & \multirow[b]{2}{*}{$\begin{array}{l}\text { Phase of rose } \\
\text { aphid }\end{array}$} & \multirow[b]{2}{*}{$\begin{array}{l}\text { Nymphal } \\
\text { instar }\end{array}$} & \multicolumn{3}{|c|}{ Observations } & \multirow[b]{2}{*}{$\begin{array}{l}\text { Duration of nymphal } \\
\text { instars }(\text { Mean } \pm S D)^{*}\end{array}$} & \multirow[b]{2}{*}{$\begin{array}{l}\text { Pre- reproductive pe- } \\
\text { riod (days) }\end{array}$} & \multirow{2}{*}{$\begin{array}{l}\text { Total develop- } \\
\text { mental period } \\
\text { (days) }\end{array}$} \\
\hline & & & 1 & 2 & 3 & & & \\
\hline & & I & 2.5 & 3.0 & 2.0 & $2.7( \pm 0.35)$ & & \\
\hline & & II & 2.5 & 2.0 & 1.5 & $2.2( \pm 0.29)$ & & \\
\hline & & III & 2.0 & 3.0 & 2.0 & $2.3( \pm 0.58)$ & & \\
\hline & Apterous & IV & 3.3 & 2.5 & 3.5 & $3.1( \pm 0.53)$ & 1.50 & 11.80 \\
\hline & & I & 3.0 & 3.5 & 2.9 & $3.1( \pm 0.32)$ & & \\
\hline & & II & 2.7 & 2.4 & 2.1 & $2.4( \pm 0.30)$ & & \\
\hline & & III & 3.0 & 2.5 & 2.8 & $2.8( \pm 0.25)$ & & \\
\hline \multirow[t]{8}{*}{ Late Spring } & Alate & IV & 5.2 & 4.5 & 4.8 & $4.8( \pm 0.35)$ & 2.93 & 16.03 \\
\hline & & I & 2.5 & 3.0 & 2.6 & $2.7( \pm 0.26)$ & & \\
\hline & & II & 1.5 & 2.0 & 2.8 & $2.1( \pm 0.65)$ & & \\
\hline & & III & 2.8 & 3.2 & 2.0 & $2.7( \pm 0.61)$ & & \\
\hline & Apterous & IV & 4.0 & 3.5 & 3.0 & $3.5( \pm 0.50)$ & 2.25 & 13.25 \\
\hline & & I & 3.7 & 3.3 & 4.0 & $3.7( \pm 0.35)$ & & \\
\hline & & II & 2.6 & 2.4 & 3.4 & $2.8( \pm 0.53)$ & & \\
\hline & & III & 3.0 & 2.5 & 3.5 & $3.0( \pm 0.50)$ & & \\
\hline Autumn & Alate & IV & 5.5 & 5.7 & 5.3 & $5.5( \pm 0.20)$ & 6.00 & 21.00 \\
\hline
\end{tabular}

${ }^{*}$ Mean of 3 replications/ season/ for each phase of aphid life.

In apterous form $2^{\text {nd }}$ instar usually took least time in comparison to other instars while for alate forms $4^{\text {th }}$ instar is the longest instar, since aphids develop wings in this very stage and as a result this instar takes more time. M. rosae showed polymorphism in its generations with predominant brown morphs in contrast to green morphs. Throughout the infestation season, colonies of rose aphids comprising of alate and apterous forms, were seen crowding on rose plants at the same time (Fig. 5).

The data on mean reproductive period, total fecundity (nymphs laid/ female) and rate of reproduction (nymphs laid/ day/ female) for apterous and alate forms in the late spring and autumn season are shown in Table 6. The data on mean duration of post reproductive period, adult longevity and total longevity of apterous form 


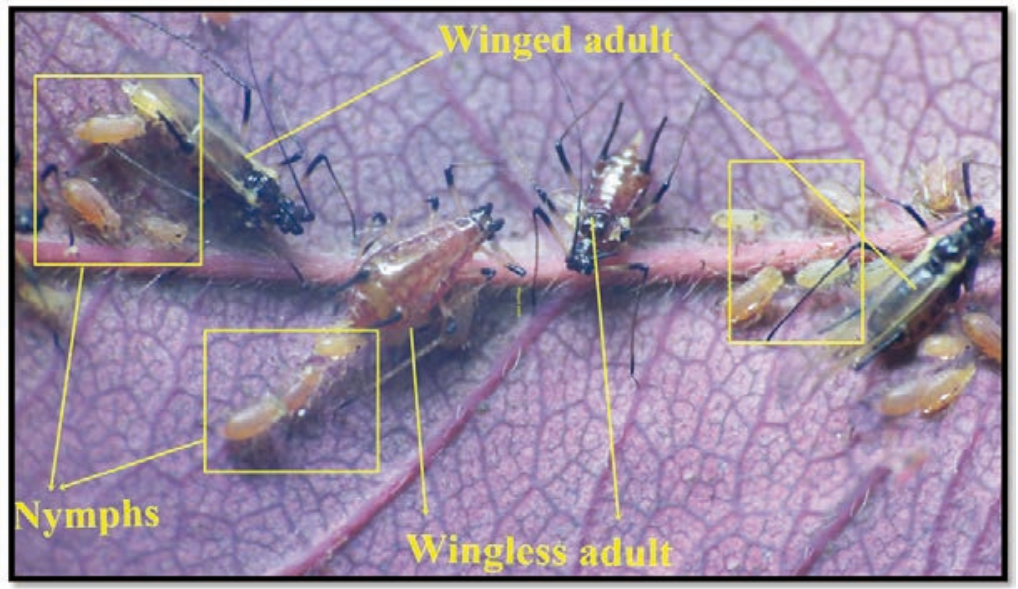

Figure 5: Colony of rose aphid depicting different phases in the life cycle of $M$. rosae

Table 6: In vitro studies on reproductive and longevity of $M$. rosae in two seasons of Kashmir

\begin{tabular}{llllllll}
\hline \multirow{2}{*}{ Season } & Phase of aphid & $\begin{array}{l}\text { Reproductive } \\
\text { period }\end{array}$ & Total fecundity & $\begin{array}{l}\text { Rate of repro- } \\
\text { duction }\end{array}$ & $\begin{array}{l}\text { Post reproduc- } \\
\text { tive period }\end{array}$ & Adult longevity Total longevity \\
\hline \multirow{2}{*}{ Late spring } & Apterous & 14.63 & 94.62 & 6.46 & 4.25 & 18.44 & 30.24 \\
\hline \multirow{2}{*}{ Autumn } & Alate & 9.80 & 50.87 & 5.19 & 8.87 & 14.36 & 30.39 \\
\hline & Apterous & 20.10 & 65.12 & 3.24 & 9.50 & 28.50 & 41.75 \\
\end{tabular}

was recorded as $4.25,18.44,30.24$ days in late spring and $9.50,28.50,41.75$ days in autumn respectively whereas for alate form the post reproductive period, adult longevity and total longevity were found to be $8.87,14.36,30.39$ days in late spring and 12.75, 23.00 and 44.00 days in autumn respectively.

The pest first appeared in the $3^{\text {rd }}$ week of March and remained active on the rose plants for about ten months of the year. Under laboratory conditions, the rose aphid was observed to complete its life cycle from $3^{\text {rd }}$ week of March to $4^{\text {th }}$ week of December, reproducing parthenogenetically, viviparously all the year round.

\subsection{RESPONSE OF DIFFERENT Rosa SPP.. TO $M$. rosae}

The results on screening of different cultivars of Rosa spp. viz. Grand Gala, Golden Gate, Konfettii, Naranga and Nobless against rose aphid, $M$. rosae are shown in Fig. 6 which clearly depicts that 'Konifitti' had least mean aphid intensity than rest of cultivars. Further, 'Grand Gala' was found to have highest mean aphid intensity during the whole growing season was designated as highly susceptible while as 'Naranga' and 'Nobless' were classified as moderately susceptible and suscep- tible respectively (Table 7). However, Golden Gate and Konfetti were grouped as resistant and highly resistant cultivars with mean aphid intensity of 1.91 and 1.58 respectively.

\section{DISCUSSION}

\subsection{SEASONAL INCIDENCE OF $M$. rosae}

During the survey of ornamental shrubs carried out for the purpose of collection of rose aphids, it was evident that this insect pest first appeared on the apical tender portions of rose pant in the $3^{\text {rd }}$ week of March in the Srinagar district (Table 1 \& 2). The findings were in close association with the prior findings of Mohammed \& Mallah (1987) and Jaskiewicz (1995) who concluded that this aphid species first appeared in the spring season on the rose shoots in mid May and mid February in Poland and Iraq respectively. A large number of aphids forming huge colonies were also observed by Bhagat \& Ahmad (1995) on Rosa spp. at Jammu during spring season. Rani \& Mohan (1997) observed the M. rosae clusters were found around the growing shoots of rose plant during Oct.- Feb. when the weather is cool and cloudy in Bangalore. However, Atwal \& Dhingra (1971) and 
Table 7: Mean aphid intensity of five cultivars of Rosa spp. at KUBG, Srinagar

\begin{tabular}{|c|c|c|c|c|c|c|}
\hline \multirow[b]{2}{*}{ S. No. } & \multirow[b]{2}{*}{ Cultivars } & \multicolumn{3}{|c|}{ Replications } & \multirow[b]{2}{*}{ Mean aphid intensity per shoot* } & \multirow[b]{2}{*}{ Response category } \\
\hline & & 1 & 2 & 3 & & \\
\hline 1 & Grand Gala & 8.00 & 5.00 & 7.00 & $20.00(4.53)$ & Highly Susceptible \\
\hline 2 & Golden Gate & 0.93 & 0.99 & 1.23 & $3.15(1.91)$ & Resistant \\
\hline 3 & Konfettii & 0.56 & 0.84 & 0.60 & $2.00(1.58)$ & Highly Resistant \\
\hline 4 & Naranga & 2.19 & 2.13 & 3.00 & $7.35(2.80)$ & $\begin{array}{l}\text { Moderately Suscep- } \\
\text { tible }\end{array}$ \\
\hline 5 & Nobless & 3.05 & 4.60 & 5.00 & $12.65(3.63)$ & Susceptible \\
\hline
\end{tabular}

* Mean of observations recorded from March to December 2015; five replications for each cultivar; figures in parenthesis are $\sqrt{x}+0.5$ transformed values.

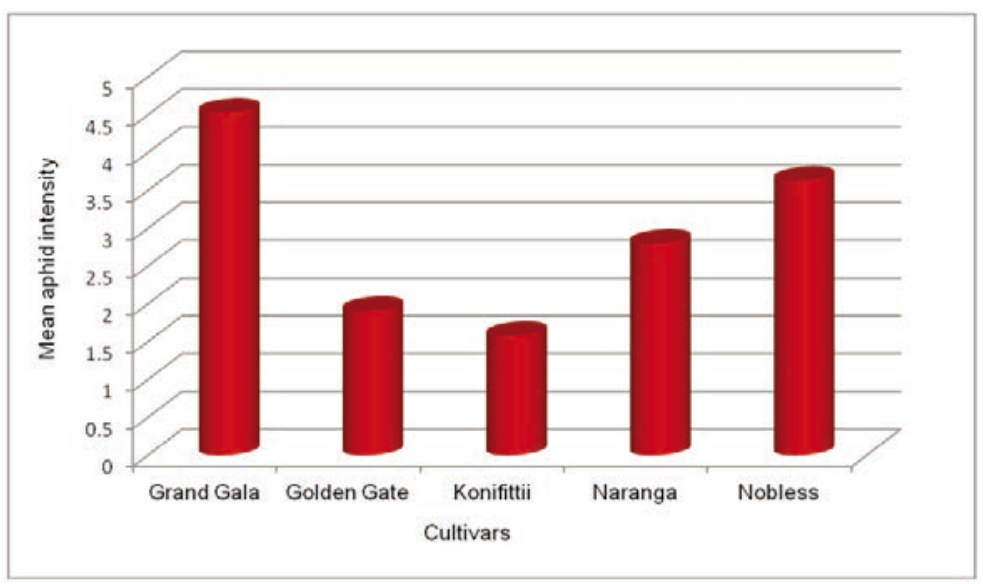

Figure 6: Relative susceptibility of different rose cultivars to M. rosae

Hole et al. (1998) reported that the pest first appears in November and $3^{\text {rd }}$ week of January in Punjab and Pune states of India respectively. This difference in appearance of pest may be ascribed to the different agroclimatic conditions/ seasons, latitudinal clines and different growth stages of host plant in the different regions of the country.

The population of aphids increased steadily, achieving its $1^{\text {st }}$ peak in the month of May when rose plants were in flowering and bud stages. Interestingly, a $2^{\text {nd }}$ peak which was lower than the $1^{\text {st }}$ one was observed in $1^{\text {st }}$ week of October. This observation was credited to the drop in high temperature and to the $2^{\text {nd }}$ flush of vegetative growth on rose bushes which augment its vulnerability to the pest. The population of pest starts declining sharply in the month of October and completely disappears thereafter in December. These observations coincide with the prior observations of Maezler (1977) who recorded three peaks of $M$. rosae in spring- summer with respect to the three growth flushes of rose in South Australia.

Thereafter, with the further fall in temperature and production of alate form of pest, population started declining further and completely vanishes from rose plants in the $3^{\text {rd }}$ and $4^{\text {th }}$ week of December. The complete disappearance of the pest from roses has been observed in different months from different regions of the world e.g. Atwal \& Dhingra (1971) reported from Punjab that the pest disappears in the month of May, at the end of October from Lublin, Poland (Jaskiewicz, 1995), by the midJune in Mosul, Iraq (Mohammed \& Mallah, 1987) and by the end of April in Pune, Maharashtra (Hole et al., 1998) which may be attributed to the agroclimatic factors, latitudinal clines and the growth stages of the rose bushes.

\subsection{PERCENTAGE OF BROWN AND GREEN MORPHS OF $M$. rosae}

In our study, two phenotypic morphs i.e. brown and green representing clones of $M$. rosae colonizing rose plants either separately or together were observed. These findings are in uniformity with many previous researchers viz. David et al. (1958), Atwal \& Dhingra (1971), Tomiuk \& Wohrmann (1990) and Chen De Qiao et al. (1997). 
As far as percentage of brown and green morphs of $M$. rosae is considered, the observed bias towards brown form is attributed to high reproductive rates and better adaptability of this morph in comparison to its green morph as suggested by Tomiuk \& Wohrmann (1990).

\subsection{PERCENTAGE OF ALATE AND APTEROUS FORMS OF M. rosae}

Throughout the study period, both apterous and alate forms were found to variable extent. In the beginning of season, percentage of alate forms increased gradually up to mid May. Atwal \& Dhingra (1971) have also observed that alate population progressively increased from the beginning of season. But as the population peaked to its maximum in the $4^{\text {th }}$ week of May, thereafter their population declined possibly in response to crowding and high temperature as suggested by Maezler (1977) and Atwal \& Dhingra (1971). Das (1918) pointed out that possibly the alate forms may be carried to high altitude cooler regions along with wind debris. The alate percentage remained very low in the hotter months but October onwards; their percentage increased progressively and towards the end of season more than $70 \%$ population was alate form. Atwal \& Dhingra (1971) observed more than $80 \%$ population as alate form towards the end of season. This urge was possibly in response to short photoperiod and maturity of host plants as suggested by Grewal \& Bains (1975) for Macrosiphum (Sitobion) avenae Fabricius, 1775. Howard and Dixon (1992, 1995) also suggested that maturity of plants induces alate production.

The production of alatae in most of aphid species is in response to increased aphid density and in some species even small increase in population triggers wing formation (Johnson, 1965; Lees, 1967; Shaw, 1970). The immediate reason for such changes appears to be increased tactile stimulation between aphids that is mainly mediated by antennae in some species (Johnson, 1965). In addition to this, the mere occurrence of particular natural enemy was known to elicit an increase in winged morph production in pea aphid, Acyrthosiphon pisum Harris, 1776 (Dixon and Agarwala, 1999; Kunert \& Weisser, 2003). The induction of winged morphs is triggered by either predator avoidance behaviour or from the release of aphid alarm pheromone (Kunert et al., 2005). Aphid or plant pathogens (i.e., fungi or viruses) and facultative aphid endosymbionts may also affect wing development (Muller et al., 2001; Leonardo and Mondor, 2006). Furthermore, several abiotic factors like temperature may influence wing induction either directly or indirectly through host plant (Johnson and Birks, 1960; Schaefers and Judge, 1971; Liu, 1994). In clones (that do not undergo sexual reproduction), appearance of wings may be ascribed to change in photoperiod (Lees, 1966). Wing development in aphids is thus an evolutionary phenomenon by which they undergo either sexual reproduction or migrate to favourable environments.

\subsection{BIOLOGY OF M. rosae}

The study of biology revealed that pest passed through four nymphal instars. This was in consonance with the findings of Atwal \& Dhingra (1971) and Mohammad \& Mallah (1987). The apterous form passed through four instars with the total longevity of 30.24 and 41.75 days in spring and autumn seasons respectively. For the alate form it was 30.39 and 44.00 days in two seasons (late spring and autumn) respectively. These observations are slightly higher than those recorded by Atwal \& Dhingra (1971) for Macrosiphum rosaeformis (Das, 1918). The variation may be due to the host/ species differences and agroclimatic conditions but in close conformity with the observations of Reshi et al., 2008 in Kashmir for $M$. rosae. Further, it was noted that the $2^{\text {nd }}$ instar of apterous form takes the least time in comparison to other instars while for the alate forms the $4^{\text {th }}$ instar took the longest time, since aphids develop wings in this very stage and as a result this instar takes more time. Similar observations were made by Mohammad \& Mallah (1987) for $M$. rosae in Somul, Iraq.

The pre- reproductive period of apterous and alate forms in late spring and autumn was 1.50, 2.25 and 2.93, 6.00 days. This is higher than $M$. rosaeformis as reported by Atwal \& Dhingra (1971) and the observed difference may be attributed to agroclimatic disparity followed by difference in pest and host plant used for the study.

As far as total developmental period of rose aphid was concerned, the present observations are in close agreement with that of Atwal \& Dhingra (1971) and Kakar \& Sood (1989) for M. rosaeformis and with Reshi et al., 2008 for $M$. rosae. In present study, mean reproductive period of apterous form in two seasons is 14.63 and 20.10 days whereas for alate form it is 9.80 and 12.35 days respectively. These are in association with the results of previous workers viz. Atwal \& Dhingra (1971) for M. rosaeformis.

This pest was observed to reproduce parthenogenetically and viviparously all the year round. Reshi et al., 2008 reported that the pest undergo 7 complete generation from 3rd week of March to $4^{\text {th }}$ week of December. The pest did not possess any sexual stage and thus appeared anholocyclic. Observations of David $(1957,1975)$ and Maezler (1977) in India and South Australia respec- 
tively supported the anholocyclic mode of reproduction in $M$. rosae on roses. Wohrmann et al., 1991 reported that the ability of German clones to undergo sexual reproduction is stronger than the Australian clones on manipulation of environmental conditions in the laboratory. He further suggested that this disparity in the mode of reproduction in $M$. rosae may be due to the genetic and environmental factors. Sexual phase is triggered by environmental changes in the temperate regions (Hille Ris Lambers 1966 and Lees, 1966) and many clones and certain aphid species have lost the ability to undergo sexual reproduction either partially or completely (Lee, 1966 and Simon et al., 1991).

\subsection{RELATIVE SUSCEPTIBILITY OF ROSE CULTI- VARS TO $M$. rosae}

The present study revealed that none of rose cultivar was found to be free from aphid infestation. Throughout the study period, variable aphid intensity was recorded on different cultivars. This is in conformity with the observations of David et al.(1958) who reported that both garden and wild roses are attacked by this insect pest. From the analysis of mean aphid intensity, it is clear that Grand Gala harboured maximum aphids whereas Konifittii had minimum mean aphid intensity. Furthermore, Naranga and Golden Gate demonstrated moderate mean aphid intensity. These are in uniformity with findings of Akhtar \& Khaliq (2003) who ascertained that none of Rosa spp. was aphid free. Further, certain rose varieties were more susceptible to the attack of thrips than others. Rani \& Sridhar (2003) observed that more no. of thrips attacked red and orange flowers than yellow flowers which may be explained by the fact that colour of rose may act as source of attractant for insect pests like thrips and aphids. A number of morphological characters (like colour, thorns etc) and presence of chemical compounds (like presence of catechin i.e. 1, 2 benzenediol) in sap of rose plant act as feeding deterrent for numerous pests as reported by Rani \& Sridhar (2003).

\section{CONCLUSIONS}

In the present study, an extensive survey of rose plants was carried out to monitor aphid populations on them. The results obtained revealed that the pest remained active for ten months of the year with its first incidence in the month of March. Maximum aphid population was observed in May after which the population declined till the month of July. The aphid population reached a $2^{\text {nd }}$ peak in the month of October. Thereafter, population plummeted till their complete disappearance in the month of December. Both alate and apterous forms of $M$. rosae were observed to pass through 4 nymphal instars in two different seasons (late spring and autumn). The developmental period, pre reproductive period, reproductive period, post reproductive period and adult longevity of apterous morphs in spring were recorded as $11.80,1.50,14.63,4.25$ and 18.44 days whereas in autumn, these phases were of $13.25,2.25,20.10,9.50$ and 28.50 days duration respectively. Alate morph of rose aphid had developmental period, pre reproductive period, reproductive period, post reproductive period and adult longevity of $16.03,2.93,9.80,8.87$ and 14.36 days in spring season. The durations of these phases in autumn season for alate morph were recorded as 21.00 , $6.00,12.35,12.75$ and 23.00 days respectively. Further, none of the rose cultivars studied during the entire growing season escaped the aphid attack. 'Konfettii' was categorized as highly resistant with lowest mean aphid intensity of just 2.00 aphids/ shoot while 'Grand Gala' was classified as highly susceptible cultivar with highest mean aphid intensity of 20.00 aphids/ shoot. In conclusion, the geographical position of Kashmir valley makes it better suited to meet huge demand of cut flowers in Middle East than Netherlands which is situated much far away from this region. As such the future research should focus on inter specific hybridization programs for development of aphid resistant cultivars of roses. This can provide much needed impetus to nascent floriculture industry of our state.

\section{REFERENCES}

Akhtar, I. H., and Khaliq, A. (2003). Impact of plant phenology and coccinellid predators on the population dynamic of rose aphid, Macrosiphum rosaeformis Das. (Aphididae: Homoptera) on rose. Asian Journal of Plant Sciences, 2(1), 119-122. https://doi.org/10.3923/ajps.2003.119.122

Anonymous (1982). Editors Vernon- H- Heywood. Popular Encyclopedia of Plants. Cambridge University Press London. New York, pp. 368.

Atwal, A. S., \& Dhingra, S. (1971). Biological studies on Macrosiphum rosaeformis Das. (Hemiptera: Aphididae) the common rose aphid. Indian Journal of Entomology, 33(2), 136- 141.

Ayci, F., Aydinli, M., Bozdemir, O. A., \& Tutas, M. (2005). Gas chromatographic investigation of rose concrete, absolute and solid residue. Flavour and Fragance Journal, 20, 481486. https://doi.org/10.1002/ffj.1487

Ayyar, R. T. V. (1984). Pests of garden and flower plants, In: Handbook of Economic Entomology for South India. International Books and Periodicals Supply Service (pp. 336337). New Delhi.

Bari, M. N. and Sardar,M. A. (1998). Control strategy of bean 
aphid with predator, Menochilus sexmaculatus (F) and insecticides. Bangladesh Journal of Entomology, $8(1,2), 21$ 29.

Basim, E., \& Basim, H. (2003). Antibacterial activity of Rosa damascena essential oil. Fitoterrapia, 74, 394- 396. https:// doi.org/10.1016/S0367-326X(03)00044-3

Bhagat, R.C., \& Ahmed, M. N. (1995). Aphid parasitoid (Hymenoptera) of aphids (Homoptera) of Jammu- new records, host range and biological notes. Journal of Aphidology, 5(1- 2), 90-96.

Blackman, R. I., \& Eastop, V. F. (2000). Lists and keys to aphids on each crop. In: Aphids on the World's Crops. pp. 466 ( $2^{\text {nd }}$ edition).

Chakrabarti, S. \& Gosh, A. K. (1970). On the rose infesting aphids (Insecta: Homoptera) in India. Indian Journal of Horticulture, 27(3- 4), 226- 232.

Chen De Qiao., Purcell, A. H. and Chen, D. Q. (1997). Occurrence and transmission of facultative endosymbionts in aphids. Current Microbiology, 34(4), 220- 25. https://doi. org/10.1007/s002849900172

David, S. K. (1957). Notes on South Indian aphids. Indian Journal of Entomology, 19(4), 298.

David, S. K., Narayanan, K., \& Rajsingh, S.G. (1958). Five new species of aphids (Homoptera) from north western India. Oriental Insects, 4, 413- 426. https://doi.org/10.1080/00305 316.1970.10433978

David, S. K. (1975). A taxonomic review of Macrosiphum (Homoptera: Aphididae) in India. Oriental Insects, 9(4), 461- 493. https://doi.org/10.1080/00305316.1975.10434515

Dennis, S. H. (1987). Agriculture insect pests of temperate region and their control. Cambridge University Press, pp. 573. Cambridge.

Dixon, A. F. G. and Agarwala, B. K. (1999). Ladybird induced life history changes in aphids. Proceedings of Royal Society London-Biological Sciences, 266, 1549- 1553. https://doi. org/10.1098/rspb.1999.0814

Gadakh, M. (2014). Efficacy of some plant extracts against rose aphid, Macrosiphum rosaeformis (Davis). International Journal of Pharmaceutical Research and Development, 6 (10), 0974- 9446.

Ghetiya, L. V. (1992). Bionomics, population dynamics and chemical control of aphid (Aphis gossypii Glover) on coriander. M. Sc. (Agri.) thesis submitted to GAU, Junagadh.

Grewal, T. S., and Bains, S. S. (1975). The role of abiotic and biotic factors in the population buildup of wheat aphids and the extent of loss caused by tem. Indian Journal of Ecology, 2(2), 139-145.

Hille Ris Lamber, D. (1966). New and little known members of the aphid fauna of Italy (Homoptera: Aphididae). Bolletino di Zoologia Agrariane di Bachicoltura, Serie, 2(8), 1- 32.

Hole, U. B., Salunkha, G. N., Reddy, P. P., Kumar, N. K. K., Verghese, A. (1998). Effect of meteorological parameters on population dynamics of aphid on rose. Advances in IPM for Horticultural crops. In: Proceedings of the First National Symposium on Pest management in Horticultural Crops: Environmental Implications and Thrusts, Bangalore, India.1517 October, 1997.

Howard, M. T., and Dixon, A. F. G. (1992). The effect of plant phenology on the induction of alatae and the development of population of Metopolophium dirhodum (Walker), the rose grain aphid, on winter wheat. Annals of Applied Biology, 120(2), 203- 213. https://doi.org/10.1111/j.1744-7348.1992. tb03418.x

Howard, M. T., and Dixon, A. F. G. (1995). Factors determining the pest status of rose grain aphid, Metopolophium dirhodum on winter barley in U. K. Annals of Applied Biology, 127(1), 1- 10. https://doi.org/10.1111/j.1744-7348.1995. tb06646.x

Jacoby, F. C \& Wokes, F. W. (1944). Carotene and lycopene in rose hips and other fruits. Biochemical Journal, 38(3), 279282. https://doi.org/10.1042/bj0380279

Jalalizand, A. R., Karimi, A., Modaresi, M., and Mahmoodi, E. (2012). Determining morphological traits and genetic diversity of rose aphids using RAPD and RFLP- PCR molecular markers. International Conference on Applied Life Science, From $10^{\text {th }}$ to $12^{\text {th }}$ Sept, Turkey. https://doi. org/10.1016/j.apcbee.2012.11.003

Jaskiewicz, B. (1995). The association of aphids feeding on shrubs of Rosa rugosa Thrumb. In the Academy Park in Lublin. Annals Universitatis Mariae Curie Sklodowska Section EEE. Horticulltura, 3, 159- 171.

Johnson, B. and Birks, P. R. (1960). Studies on wing polymorphism in aphids I. The development process involved in the production of different forms. Entomologia Experimentalis et Applicata, 3, 327- 339. https://doi. org/10.1111/j.1570-7458.1960.tb00461.x

Johnson, B. (1965). Wing polymorphism in aphids II. Interaction between aphids.. Entomologia Experimentalis et Applicata, 2, 82-99. https://doi.org/10.1111/j.1570-7458.1966. tb02352.x

Kunert, G. and Weisser, W. W. (2003). The interplay between density and trait- mediate effects in predator- prey interactions: a case study in aphid wing polymorphism. Oecologia, 135, 304- 312. https://doi.org/10.1007/s00442-003-1185-8

Kunert, G., Otto, S., Rose, S. R., Geshenzon, J. and Weisser, W. W. (2005). Alarm pheromone mediates production of winged dispersal morphs in aphids. Ecology Letters, 8, 596603. https://doi.org/10.1111/j.1461-0248.2005.00754.x

Lees, A. D. (1966). The control of polymorphism in Aphids. Advances in Insect physiology, 3, 207- 277. https://doi. org/10.1016/S0065-2806(08)60188-5

Lees, A. D. (1967). The production of the apterous and alate forms in the aphid, Megoura viciae Buckton, with special reference to the role of crowding. Journal of Insect Physiology, 13, 289- 318. https://doi.org/10.1016/00221910(67)90155-2

Leonardo, T. E. and Mondor, E. B. (2006). Symbiont modifies host life history traits that affect gene flow. Proceedings Royal Society B-Biological Sciences, 273, 1079- 1084. https:// doi.org/10.1098/rspb.2005.3408

Liu, S. S. (1994). Production of alatae in response to low temperature in aphids: a trait of seasonal adaptation. In: Danks HV (ed) Insect Life- cycle Polymorphism: Theory, Evolution and Ecological Consequences for Seasonality and Diapause Control, Kluwer Academic Publishers: Dordrecht. pp. 245261. https://doi.org/10.1007/978-94-017-1888-2_12

Maezler, D. A. (1977). The biology and main causes of changes in numbers of the rose aphid (Macrosiphum rosae $\mathrm{L}$ ) on cul- 
tivated roses in South Australia. Australian Journal Zoology, 25(2), 269- 284. https://doi.org/10.1071/ZO9770269

Mahmood, N., Piacente, S., Pizza, C., Burke, A., Khan, A. I., and Hay, A. J. (1996). The anti HIV activity and mechanisms of action of pure compounds isolated from Rosa damascena. Biochemical and Biophysical Research Communications, 229, 73- 79. https://doi.org/10.1006/bbrc.1996.1759

Malik, Y. P., and Deen, B. (1998). Response of mustard varieties to aphid, Lipaphis erysimi infestation in Uttar Pradesh. Indian Journal of Entomology, 60(3), 91- 92.

Mandahar, C. L. (1987). Introduion to plant viruses. S. Chand and Co. pp. 568. New Delhi, India.

Mehrparvar, M., Mansouri, S. M. and Hatami, B. (2016). Some bioecological aspects of the rose aphid, Macrosiphum rosae (Hemiptera: Aphididae) and its natural enemies. Acta Universitatis Sapientiae Agriculture and Environment, 8, 74- 88. https://doi.org/10.1515/ausae-2016-0007

Mohammed, M. A., and Mallah, N. M. (1987). Ecological and biological studies on the rose aphid (Macrosiphum rosae L) (Homoptera: Aphididae) in Mosul region, Iraq Arab Journal of Plant Protection, 5(2), 53- 58.

Muller, C. B., Williams, I. S., Hardie, J. (2001). The role of nutrition, crowding and interspecific interactions in the development of winged aphids. Ecological Entomology, 26, 330340. https://doi.org/10.1046/j.1365-2311.2001.00321.x

Rani, J. B., Mohan, N. J. (1997). Pest management in ornamental crops. In: Progressive Floriculture (Eds. I. S. Yadav and M. L. Choudhary) pp. 169- 181. House of Sarpan, Bangalore.

Rani, J. B., and Sridhar, V. (2003). Screening of polyhouse grown rose varieties for their resistance to thrips, Scritothrips dorsalis Hood. Journal of Ornamental Horticulture, 6(3), 165- 171.

Reshi, F. A., Wani, A. R., Wani, N. A. (2008). Biological studies of common rose aphid Macrosiphum rosae L. (Hemiptera:
Aphididae) in Kashmir. SKUAST Journal of Research, 10, 31-36.

Schaefers, G. A. and Judge, F. D. (1971).Effects of temperature, photoperiod and host plant on alary polymorphism in the aphid, Chaetosiphon fragaefolii. Journal of Insect Physiology, 17, 365- 379. https://doi.org/10.1016/0022-1910(71)902204

Shaw, M. J. P. (1970). Effect of population density on alienocolae of Aphis fabae Scop. I. The effect of crowding on the production of alatae in the laboratory. Annals of Applied Biology, 65, 191- 196. https://doi.org/10.1111/j.1744-7348.1970. tb04578.x

Simon, J. C., Blackman, R. L., Gallic, J. F. (1991). Local variability in the life cycle of the bird cherry- oat aphid, Rhopalosiphum padi (Homoptera: Aphididae) in western France. Bulletin of Entomological Research, 81, 315- 322. https://doi. org/10.1017/S0007485300033599

Tomiuk, J., Wohrmann, K., Bohm, I., Stamp, J. (1990). Variability of quantitative characters and enzyme loci in rose aphid populations. Entomologist, 109(2), 84- 92.

Wohrmann, K., Hales, D. F., Tomiuk, J., Rettenmeir, G. (1991). Induction of sexual forms of the rose aphid, Macrosiphum rosae. Entomologia Expermentalis- et-Applicata, 61(1), 1724. https://doi.org/10.1111/j.1570-7458.1991.tb02391.x

Zehnder, G., Gurr, G. M., Kuhne, S., Wade, M. R., Wratten, S. D. and Wyss, E. (2007). Arthropod pest management in organic crops. Annual Review of Entomology, 52, 57- 80. https://doi.org/10.1146/annurev.ento.52.110405.091337

Ziegler, S. J., Meier, B., Sticher, O. (1986). Fast and selective assay of 1- ascorbic acid in Rose hips by RP- HPLC coupled with electrochemical and/ or spectrophotometric detection. Planta Medica, 52(2), 383- 387. https://doi. org/10.1055/s-2007-969192 